\title{
A Review on Integrated Nutrient Management in Agriculture
}

\author{
Deepali Bakshi*, Sonika Kalia and Monika Kalia \\ Department of Agriculture, Chandigarh Group of Colleges, Technical Campus, \\ Jhanjeri, Mohali, Punjab (140307), India \\ *Corresponding author
}

\section{A B S T R A C T}

Ke y w o r d s
Organic, Integrated
Nutrient
Management,
sustainable, manure,
fertility

The excess usage of synthetic fertilizers with minimum application of organic inputs results into nutrient deficiencies, deterioration of soil and also causes environment pollution. It also affects the sustainability of agricultural production. Sustainable agricultural production includes the management of soil organic carbon, use of organic manure such as animal manure, green manure, crop residues, and sewage sludge. Since only organic manure cannot fulfill the nutrient demands of agriculture crops, hence integration of fertilizers and organic sources is the need of the hour. Under such circumstances, integrated nutrient management has come up as finest technology in present era. The INM technology enriches the agricultural crops with all essential nutrients, increases production, and sustains productivity \& fertility of soil. It is the integrated use of organic manures and chemical fertilizers which encompasses crop rotations, introduction of legumes, and efficient management of water, weed and insectpest. The improvement in nutrient application methods in association with timing of application is helpful in achieving the maximum efficiency of integration of organic and inorganic source of nutrients.

\section{Introduction}

To meet the increasing demand of food, the growing population put a lot of pressure on agriculture and natural resources. This is now significant challenge in the developing world to meet the food demands of growing population and to meet these challenges sometimes farmers use harmful inputs such as chemicals which leads to deterioration of soilplant-microbes environmental system. The soil-plant-microbe system plays an important role in soil fertility maintenance and production of crops. The estimated annual cost of environmental degradation in some countries ranges from $4-17 \%$ of gross national product.

By using inappropriate agricultural practices, deforestation and overgrazing in the developing world, $3 / 4^{\text {th }}$ of the area is degraded and eroded. Also, with increase in population, it is very difficult to maintain food security. In India, nutrient management played an important role in increasing food grain production from 52 MT in 1951-52 to 
230 MT during 2007-2008. The excessive use of fertilizers leads to nutrient use efficiency, making consumption of fertilizer uneconomical and producing adverse effects on environment, groundwater quality which cause disturbance in environment and ultimately causing health hazards. Hence there is a need to use organic manure in combination with chemical fertilizers for sustainable crop production and different nutrient sources integration is an outstanding strategy for sustained productivity and fertility.

\section{Concept of integrated nutrient management}

For increasing agricultural production, nutrients play an important role. The method of application of fertilizer, its nature and time of application influences the recovery of added nutrients. For example, ammonium nitrate is the best source of nitrogen among nitrogenous fertilizer for upland crops whereas ammonical and amide form of nitrogen are considered best among nitrogenous fertilizers for rice crop. For application of $\mathrm{N}$, split application is superior to basal application. For Phosphorus, basal application is applied and in light textured soils, split application of $\mathrm{K}$ is preferred. In the developed world, by using management practices such as the application of P-based fertilizer/manure, most cereal growing areas will overcome the problem of low $\mathrm{P}$ availability (Ortiz- Monasterio et al., 2002). The availability of Phosphorus is affected by soil $\mathrm{pH}$ and is maximum when $\mathrm{pH}$ of soil is in between 5.5 and 7.5. In soils with $\mathrm{pH}<5.5$, acid soil conditions cause dissolution of aluminum and iron minerals which precipitates with solution $\mathrm{P}$ whereas in soils with $\mathrm{pH}>7.5$, basic soil conditions cause excessive calcium present in soil solution which precipitates with Phosphorus ultimately decrease the availability of Phosphorus.
Integrated nutrient supply not only improves the physical, chemical and biological health of soil and increases the availability of both applied and native soil nutrients but also helps in retarding degradation of soil, deterioration of water and environmental quality by enhancing carbon sequestration and checking the losses of nutrient to water bodies and atmosphere. The one of the advantages of using organic sources is that it acts as slow release fertilizer and synchronizes the demand of nutrient by the plants, both in time and space, with supply of the nutrients from the labile soil and applied nutrient pools.

\section{Components of integrated nutrient management (INM)}

The various components of integrated nutrient management are: a) integration of soil fertility b) crop residues recycling c) use of organic manures d) biological agent e) genotypes f) balanced fertilizer nutrients.

\section{The main principles of integrated nutrient management (INM)}

The main principles of INM includes: a) all sources of nutrients to optimize their input $b$ ) matching soil nutrient supply with crop demand c) reducing nitrogen losses. The timing and amount of nutrient application in accordance with the crop nutrient requirements, is necessary to achieve maximum yields and improve nutrient-use in Integrated nutrient Management (Cassman et al., 2002). It was also studied by Witt and Dobermann (2004) that nitrogen fertilizers with frequent application can potentially reduce nitrogen losses and increasing yield and quality of crop. It was also reported by $\mathrm{Li}$ et al., (2015) that fate of Nitrogen is an integrated consequence of Nitrogen uptake, immobilization, Nitrogen losses like volatilization, denitrification, leaching and runoff. 
Integrated nutrient management on soil fertility

The increasing fertility of soil and crop productivity through use of chemical or synthetic fertilizers has oftenly affected negatively on biogeochemical cycles was also reported by Roberts (2008). Also usage of fertilizer caused leaching and run-off of nutrients, especially nitrogen $(\mathrm{N})$ and phosphorus (P) results in degradation of environment. The different sources of nutrients which enhance the productivity of crops are: manure, biofertilizers, soil, irrigation water, and atmosphere. The removal of nutrients by crops from the soil exceeded their restoration through fertilizers; manures causing unbalanced nutrients in soil were also reported by Gangawar and Prasad (2005). It was also observed by Kumar et al., (2009) that organic manures in combination with fertilizers will surely enhance crop growth.

\section{Integrated nutrient management on crop productivity}

To increase the productivity of crops, there should be proper nutrient and soil health management. Integrated nutrient management among all strategies of sustainable crop production plays a significant role through reducing chemical fertilizers (Singh and Sinsinwar, 2006). It has also been reported by Prasad (2008) that organic manures in combination of chemical fertilizers improve high yield of crop as compare to only fertilizers. The addition of organic manure, lime and bio-fertilizers enhanced soil organic carbon, moisture retention capacity, infiltration rate (Saha et al., 2010). Biofertilizers promote fertilizer nutrient use through biological nitrogen fixation systems, which further solubilize fewer mobile nutrients and leads to stable and sustainable agriculture system (Meena et al., 2013; Meena et al., 2014b; Meena et al., 2014a).

\section{References}

Cassman, K.G., Dobermann, A. and Walters, D.T. 2002. Agro ecosystems, nitrogen use efficiency and nitrogen management. Ambio, 31:132-140.

Gangwar, B., Prasad, K. 2005. Cropping system management for mitigation of second generation problems in agriculture. Indian Journal of Agriculture Science 75: 65-78.

Kumar, A.S., Sharma, A., Mishra S. 2009. Application of farmyard manure and vermicompost on vegetative and generative characteristics of Jatropha curcus. Journal of phytology 1(4): 206222.

Li, Y., Simunek, J., Zhang, Z., Jing, L. and $\mathrm{Ni}$, L. 2015. Evaluation of nitrogen balance in a direct-seededrice field experiment using Hydrus-1D. Agril. Water Mgt. 148:213-222.

Meena, O.P., Maurya, B.R., Meena, V.S. 2013. Influence of K- solubilizing bacteria on release of potassium from waste mica. Agri. Sustain.Dev. 1(1): 5356.

Meena, V.S., Maurya, B.R., Bahadur, I. 2014b. Potassium solubilization by bacterial strain in waste mica. Bangladesh J. Bot. 43(2): 235-237.

Meena, V.S., Maurya, B.R., Verma, J.P. 2014a. Does a rhizospheric microorganism enhance $\mathrm{K}+$ availability in agricultural soils?. Microbiol. Res. 169: 337-347.

Ortiz-Monasterio JI, Pena RJ, Pfeiffer WH and Hede AH. 2002. Phosphorus use efficiency, grain yield, and quality of triticale and durum wheat under irrigated Conditions Proceedings ofthe 5th International Triticale Symposium, Annex June 30 - July 5, Radzików,Poland.

Prasad, R. 2008. Integrated plant nutrient supply system (IPNS) for sustainable 
agriculture. Indian J. Ferti.4 (12): 71-90.

Roberts TL. 2008. Improving nutrient use efficiency. Turkish Journal of Agriculture and Forestry32:177-182.

Saha, R., Mishra V.K., Majumdar, B., Laxminarayana, K. and Ghosh, P.K. 2010. Effect of integrated nutrient management on soil physical properties and crop productivity under a maize (Zea mays) -mustard (Brassica campestris) cropping sequence in acidic soils of northeast India. Commun. Soil Sci. \& Plant Ana.41: 2187-2200.

Singh, R., Sinsinwar, B.S. 2006. Effect of integrated nutrient management on growth, yield, oil content and nutrient uptake of Indian mustard (Bressica junecea). Indian Journal of Agricultural Sciences 76(5):322-324.

Witt, C., and Dobermann, A. 2004. Toward a decision support system for site-specific nutrient management. In: Dobermann, A., Witt, C. and Dawe, D. (Eds.), Increasing the productivity of intensive rice systems through site-specific nutrient management. Science Publishers, Inc., and International Rice Research Institute (IRRI), Enfield, NH (USA) and Los Baños (Philippines), pp. 359-395.

\section{How to cite this article:}

Deepali Bakshi, Sonika Kalia and Monika Kalia. 2020. Brief Review on Integrated Nutrient Management in Agriculture. Int.J.Curr.Microbiol.App.Sci. 9(06): 2067-2070. doi: https://doi.org/10.20546/ijcmas.2020.906.253 